\title{
What makes good guidelines?
}

\author{
Wolfgang Gaebel \\ From $1^{\text {st }}$ International Congress on Neurobiology and Clinical Psychopharmacology and European \\ Psychiatric Association Conference on Treatment Guidance \\ Thessaloniki, Greece. 19-22 November 2009
}

In the last two decades, a large number of national and international treatment guidelines have been developed, to assist practioners in making decisions based on available evidence. However, according to a survey of schizophrenia practice guidelines for example [1], the methodological quality of the most guidelines was at best moderate. Hence, national and international institutions attempted great efforts to enhance guideline quality by describing and establishing characteristics for structure and process of their development. Beyond that, a 'good' guideline is expected to be effective, and thus to enhance outcome. Accordingly, an overview regarding methodological criteria for guideline development will be given. In addition, the results of empirical studies focusing the impact of treatment guidelines on health outcome will be summarized. As to the conclusions, developing guidelines based on highest methodological criteria is mandatory, however expectations regarding enhanced outcome in health care should be scaled down.

Published: 22 April 2010

\section{Reference}

1. Gaebel, et al: Schizophrenia practice guidelines: international survey and comparison. BJP 2005, 248-55.

Submit your next manuscript to BioMed Central and take full advantage of:

- Convenient online submission

- Thorough peer review

- No space constraints or color figure charges

- Immediate publication on acceptance

- Inclusion in PubMed, CAS, Scopus and Google Scholar

- Research which is freely available for redistribution

Submit your manuscript at www.biomedcentral.com/submit

\section{( Biomed Central}

